\title{
URGENSI SUNAH DALAM PENETAPAN HUKUM ISLAM
}

\author{
Ririn Fauziah \\ Institut Agama Islam Sunan Giri Bojonegoro \\ shonafauziyah@gmail.com
}

\begin{abstract}
"Sunnah as one of the sources of Islamic law that occupies the second position after alQur'an, it is still a matter of disputed. The dispute stems from differences of opinion about the legal force contained in the sunnah, which includes binding and has the power to emulate or not. These differences of opinion have different legal consequences. The position and urgency of sunnah in the formation of Islamic law also did not escape from the dispute. Some scholars believe that the sunnah as the second source of law is capable of independently establishing the law, but some others assume that the sunnah is not a source of law-settlers but rather the explanation and detailing, so that anything born from sunnah has actually been covered in al-Qur'an 'an. Sunnah serves to explain and strengthen the laws that already exist in alQur'an. Sunnah also provides the details and interpretations of the verses of al-Qur'an that are still mujmal or global, providing limits on the things that have not been limited, giving specificity (takhsis) on the verses that are general, and provide explanations of things which is still complicated in al-Qur'an. Sunnah also serves as the forming of a new law that does not exist in al-Qur'an."
\end{abstract}

Keyword: Sunah, Islamic Law

\section{Pendahuluan}

Sunah sebagai salah satu sumber hukum Islam yang menduduki posisi kedua setelah al-Qur'an, ternyata masih menjadi hal yang diperselisihkan. Perselisihan tersebut bersumber dari perbedaan pendapat mengenai kekuatan hukum yang dikandung sunah tersebut, yakni termasuk yang mengikat dan mempunyai kekuatan untuk diteladani atau tidak. Perbedaan pendapat ini menimbulkan akibat hukum yang berbeda pula.

Adakalanya kapasitas Rasul SAW sebagai utusan Allah yang mendapat perlakuan khusus tidak difahami oleh umatnya sehingga umatnya mengikuti segala perbuatan yang dilakukan Rasul SAW yang sebenarnya hal tersebut hanya dikhususkan bagi Rasul SAW dan 
tidak diperbolehkan bagi umatnya untuk mengikutinya, seperti menikah lebih dari empat orang istri, dan sebagainya.

Kedudukan sunah dan urgensinya dalam pembentukan hukum Islam juga tak luput dari perselisihan. Sebagian ulama meyakini bahwa sunah sebagai sumber hukum kedua mampu dengan mandiri menetapkan hukum, namun sebagian yang lain beranggapan bahwa sunah bukan merupakan sumber penetap hukum tetapi lebih pada penjelas dan merinci, sehingga apa-apa yang lahir dari sunah sesungguhnya telah tercover di dalam al-Qur'an. Oleh karena itu, pada tulisan ini akan dibahas mengenai sunah, macam-macamnya, dan kedudukan serta urgensinya dalam pembentukan hukum islam.

\section{Sunah: Definisi dan Macam-macamnya}

Sunah menurut bahasa adalah: jalan (cara) yang biasa dilakukan, baik berupa cara yang baik atau buruk. Menurut istilah ulama ushul, Sunah adalah: segala suatu yang bersumber dari Rasulullah SAW berupa perkataan, perbuatan, dan ketetapan, dari segi kedudukannya sebagai salah satu sumber hukum Islam. ${ }^{1}$ Syi'ah memandang sunah sebagai segala sesuatu yang disandarkan pada orang yang ma'sum (terjaga dari segala perbuatan hina, dosa, dan maksiat) baik berupa perkataan, perbuatan, atau penetapan. Mereka beranggapan bahwa yang ma'sum bukan hanya Rasul SAW, tetapi keturunan dari Fatimah dan Ali (ahl albait) juga merupakan orang-orang yang ma'sum dan dapat dijadikan sebagai sumber . 2

Sunah dari segi dzatnya dibagi menjadi 3 macam, yaitu: sunah qauliyah, sunah fi'liyah, dan sunah taqrïiyah.

a. Sunah qauliyah adalah: segala yang diucapkan Rasul SAW baik dalam bentuk pernyataan, anjuran, perintah, cegahan, maupun larangan ${ }^{3}$. Seperti hadis di bawah ini:

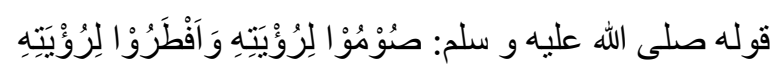

Rasul SAW bersabda: "berpuasalah karena melihat hilal dan berbukalah (tidak puasa) karena melihat hilal".

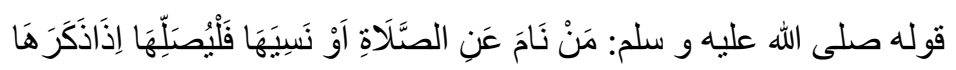

Rasul SAW bersabda: barang siapa yang tidak shalat karena tertidur atau karena lupa maka hendaklah ia mengerjakan shalat itu ketika ia telah ingat. ${ }^{4}$

\footnotetext{
${ }^{1}$ Musthafa Ibrahim. Asbābu ikhtilafi al-fuqahā fi al-ahkām al-syar'iyyah (Bagdad: Darul Arabiyyah, 1987), 255.

${ }_{2}^{2}$ Amir Syarifuddin. Ușūl al-Fiqh (Jakarta: Logos Wacana Ilmu, 1997), 75.

${ }^{3}$ Tim Penyusun Studi Islam IAIN Ampel. Pengantar Studi Islam (Surabaya: Sunan Ampel Press, 2010), 52.
} 
b. Sunah fi'liyah ('amaliyah): segala perbuatan Rasul SAW yang dilihat oleh para sahabat mengenai masalah ibadah, muamalah, dan sebagainya. Seperti cara Rasul SAW melaksanakan shalat, puasa, haji, dan lain-lain. ${ }^{5}$ Para ulama membagi sunah fi'liyah dari segi kekuatan untuk diteladani dan mengikat ke dalam tiga bagian, yaitu:

1. Perbuatan Rasul SAW sebagai manusia biasa atau berupa adat kebiasaan, seperti: cara makan, minum, duduk, berdiri, berpakaian, memelihara jenggot, dan sebagainya.

Mengenai kekuatan mengikat untuk diteladani atau tidak, para ulama berbeda pendapat. Sebagian ulama berpendapat bahwa perbuatan Rasul SAW semacam ini merupakan sunah yang memiliki kekuatan hukum untuk diikuti meskipun hanya dihukumi sunah (mandub). Sedang ulama yang lain menganggap perbuatan Rasul SAW hanya sebagai adat kebiasaan sehingga tidak memiliki kekuatan hukum untuk diteladani. ${ }^{6}$

Namun, segala suatu yang dilakukan oleh Rasulullah SAW sebagai manusia, bukan sebagai Rasul, ada kemungkinan boleh dilakukan baginya dan bagi umatnya, dan umatnya disunahkan untuk mengikutinya.

2. Perbuatan Rasul SAW yang dikhususkan hanya untuk Rasul SAW, seperti: wajibnya șalat ḍuha, witir, tahajjud tengah malam, dan berkurban. Perbuatan ini hanya diwajibkan bagi Rasul SAW dan disunahkan bagi umatnya. Sedang mengenai masuk Makkah tanpa ihram dan nikah lebih dari empat istri, hanya dikhususkan bagi Rasul SAW dan merupakan hal yang haram dilakukan bagi umat.

Jadi segala suatu yang sudah pasti merupakan kekhususan bagi Rasul SAW, tidak perlu diikuti oleh umatnya kecuali ada dalil yang mengharuskan atau membolehkan kita untuk mengikutinya.

3. Perbuatan Rasul SAW yang berisi penjelasan hukum, seperti: tata cara s\}alat, puasa, cara melakukan jual-beli, utang-piutang, dan sebagainya. ${ }^{7}$ Perbuatan Rasul SAW yang berupa penjelasan ini terbagi menjadi dua bagian yaitu:

a) Merupakan penjelas terhadap apa-apa yang terdapat dalam al-Qur'an yang masih memerlukan penjelasan. Hukum yang timbul dari penjelasan Rasul

\footnotetext{
${ }^{4}$ Muhammad Abu Zahrah. Ușül al-Fiqh (Kairo: Dar al-Fikr al-Arabi, t. th), 82.

${ }^{5}$ Zufran Rahman. Kajian Sunah Nabi SAW Sebagai Sumber Islam: Jawaban Terhadap Aliran Inkar Sunah (Jakarta: CV Pedoman Ilmu Jaya, 1995), 11.

${ }^{6}$ Amir syarifuddin. Ușül Fiqh................, 78-79.

${ }^{7}$ Musthafa Ibrahim. Asbāb al-ikhtilāfi al-fuqahā fi al-ahkam al-syar’iyyah. $257-259$
} 
SAW itu mengikuti hukum yang ada dalam al-Qur'an, baik dalam bentuk wajīb, nadb maupun ibāhah.

b) Memberi petunjuk kepada umat bahwa perbuatan tersebut boleh dilakukan.

Para ulama sepakat mengenai perbuatan Nabi yang merupakan penjelas hukum untuk umat dan menjadi dalil hukum harus dipatuhi oleh umat.

Perbuatan Rasul SAW yang tidak ada keterangan yang menunjukkan bahwa itu merupakan penjelas hukum, tidak membenarkan dan tidak menolak terbagi menjadi dua, yaitu:

1) Terdapat tujuan ibadah atau pendekatan diri kepada Allah. Pada hal ini terjadi perbedaan pendapat tentang kedudukan hukumnya. Madhab Hanabilah dan Mu'tazilah mengatakan bahwa perbuatan tersebut mengarah pada hukum wajīb untuk Rasul SAW dan umatnya. Madhab Syafi' dan pengikutnya berpendapat bahwa hal tersebut hanya merupakan nadb. Madhab Maliki menghukumi mubah, dan sebagian pengikut madhab Syafi'i tidak memberi komentar.

2) Tidak jelas memiliki tujuan ibadah atau pendekatan diri kepada Allah. Dalam hal ini terdapat empat pendapat berbeda, yaitu: wajīb menurut ibn Suraikh, at-Tabari, dan sebagian pengikut Syafi'i. Sunah menurut Hanafi, Syafi'i dan Mu'tazilah. Mubah menurut Malik dan Hanbali. Sedang Asy'ariyah memilih al-tawaquf (tidak berkomentar sampai datangnya dalil). ${ }^{8}$

Segala sunah Rasul SAW yang berupa penjelasan terhadap sesuatu maka hukumnya sama seperti sesuatu yang dijelaskan. Selain itu, perbuatan Rasul SAW dianggap sunah (untuk diikuti umatnya) apabila tidak ada dalil yang mewajibkannya, sebab apa yang keluar dari Rasul SAW dalam kapasitasnya sebagai seorang Rasul tidak menunjukkan kebolehan (mubah) untuk diikuti juga tidak menunjukkan kewajiban untuk diikuti bila tidak ada petunjuk atau dalil yang mewajibkannya.

c. Sunah Taqririyah adalah: sikap diam Rasulullah SAW saat mengetahui peristiwa yang dilakukan para sahabat baik berupa ucapan, atau perbuatan, baik kejadian itu terjadi di hadapan Rasul SAW atau berita tersebut sampai kepada Rasul SAW. Oleh karena Rasul diutus untuk menjelaskan syariat Islam dan menentang segala yang bertentangan dengan syariat, maka diamnya Rasul SAW berarti persetujuan dari beliau terhadap perbuatan atau ucapan tersebut. Sebagaimana ketika Rasul SAW berkata kepada para sahabat yang menemaninya dalam perang Bani Quraidhah: "janganlah salah satu dari kalian s\}alat 
ashar kecuali di Bani Quraidhah”, para sahabat berbeda pendapat dalam memahami perkataan tersebut. Sebagain sahabat memahami ucapan itu secara harfiah sehingga mereka mengakhirkan shalat Ashar sampai tiba di Bani Quraidhah, sedang sebagian yang lain memahami bahwa ucapan itu merupakan perintah agar bergegas supaya tidak terlambat untuk meyerang musuh sehingga mereka tetap melaksanakan s\}alat ashar saat itu (sebelum sampai Bani Quraidhah). Ketika berita itu sampai pada Rasul SAW, beliau membenarkan kedua kelompok tersebut.

\section{Dampak Perbedaan Dalam Masalah-Masalah Cabang (Fiqh)}

\section{A. Perbedaan pendapat mengenai hukum berkurban}

Sebagian ulama berpendapat bahwa hukum berkurban adalah wajib sebagaimana yang diucapkan Rabi'ah dan Malik didalam riwayatnya, Auza'i, Laits bin Sa'ad, Zafar dan Hasan. Sedangkan Imam Hanafi merincinya sebagai berikut: jika harta seseorang telah mencapai satu nisab maka wajib baginya berkurban, tapi jika belum sampai satu nisab maka tidak wajib berkurban dan jika waktu berkurban telah lewat maka tidak wajib mengulangnya. Sedangkan mayoritas ulama seperti Syafi'i, Hanbali, Syi'ah dan beberapa tokoh Maliki mengatakan bahwa berkurban adalah sunah muakkad bagi yang mampu. Hal ini sebagaimana menurut Abu Bakar, Umar, Usman, Ibnu Mas'ud dan beberapa sahabat lainnya.

Adapun sebab perbedaan pendapat itu adalah perbedaan pemahaman mengenai perbuatan Rasul SAW dalam berkurban itu wajib atau sunah. Ulama yang mengatakanya wajib maka menegaskan bahwa berkurban juga wajib, sementara ulama yang mengatakan perbuatan Rasul itu hukumnya sunah maka mereka menegaskan bahwa berkurban itu hukumnya sunah.

a) Perbedaan pendapat mengenai tayamum

Diriwayatkan dari Amr bin Ash bahwasannya: "aku mimpi basah pada waktu perang yang berkepanjangan, lalu aku berpikir bahwa jika mandi maka aku mungkin akan rusak (sakit), lalu aku memutuskan untuk bertayamum dan shalat subuh dengan para sahabat”. Kemudian hal itu diceritakan kepada Rasul SAW. Kemudian Rasul SAW berkata: "Hai Amr, engkau shalat dengan para sahabat dalam keadaan junub”. Lalu aku (Amr bin Ash) berkata: “saya mendengar Allah berfirman: Janganlah engkau membunuh dirimu karena sesungguhnya Allah itu menyayangimu”. Kemudian Rasul tidak mengingkari (menyalahkan) Amr bin Ash. 
Mayoritas ulama menegaskan kebolehan tayamum bagi orang yang menemukan air apabila ia takut untuk menggunakanya karena cuaca yang sangat dingin. Mayoritas mereka bersandar pada pengakuan Rasul SAW pada Amr bin Ash dalam cerita di atas, sedang sebagian yang lain bersandar pada qiyas yakni mengqiyaskan cuaca yang sangat dingin dengan orang sakit. Sedangkan ulama mazhab Hanafi berpendapat bahwa tidak boleh bertayamum karena alasan cuaca dingin kecuali jika berhadas besar, sebab akan membahayakan jika mandi. Sementara orang yang berhadas kecil tidak boleh tayamum kecuali jika akan membahayakan bila menggunakan air.

Sebagian ulama menerangkan bahwa ayat al-Quran membatasi hal-hal yang diperbolehkan tayamum, sehingga takut menggunakan air karena terlalu dingin, tidak termasuk di dalamnya. Adapun sebab perbedaan itu adalah perbedaan mereka dalam mengambil (menggunakan sebagai dalil) sunah taqrïriyah pada kasus Amr bin Ash, di mana ulama Hanafiyah mengambilnya dan mengkhususkannya untuk hadas besar saja, karena Amr bin Ash (pada persitiwa itu) sedang berhadas besar. Sedangkan mayoritas ulama tidak membatasi hanya hadas besar saja, namun hadas kecil juga diperbolehkan tayamum karena alasan di atas, sebab tidak ada perbedaan di antara keduanya. ${ }^{9}$

\section{Kedudukan Sunah dan Urgensinya dalam Penetapan Hukum Islam}

Para ulama telah sepakat bahwa sunah merupakan salah satu sumber hukum islam yang menempati posisi kedua setelah al-Qur'an. Hal ini disandarkan pada:

1. Al-Qur'an

Allah SWT mewajibkan umat Islam untuk menaati Rasul-Nya sebagaimana yang terdapat dalam beberapa ayat al-Qur'an seperti: dalam surat ali imran dan al-Nisa' berikut:

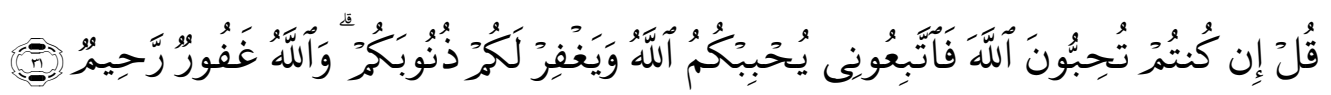

"Katakanlah: "Jika kamu (benar-benar) mencintai Allah, ikutilah aku, niscaya Allah mengasihi dan mengampuni dosa-dosamu." Allah Maha Pengampun lagi Maha Penyayang". 10

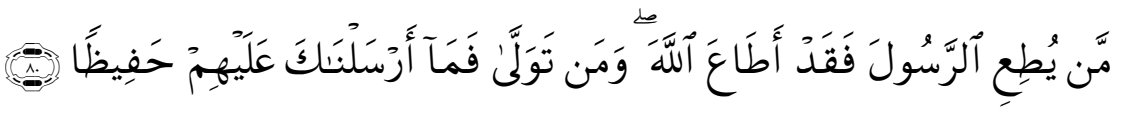

\footnotetext{
${ }^{9}$ Ibrahim, Asbab al-ikhtilafi al-fuqaha fi al-ahkam al-syar'iyyah. $261-262$

${ }^{10}$ QS. Ali Imran (3): 31.
} 
Ririn Fauziah

"Barangsiapa yang mentaati Rasul itu, Sesungguhnya ia Telah mentaati Allah. dan barangsiapa yang berpaling (dari ketaatan itu), Maka kami tidak mengutusmu untuk menjadi pemelihara bagi mereka". 11

Selain kedua ayat di atas, terdapat beberapa ayat lain yang menjelaskan tentang kewajiban menaati Rasul SAW, diantaranya: surat al-Nisa' (64), al-Nahl (4), al-Ahzab (36) dan sebagainya. Ini menunjukan bahwa sunah Nabi merupakan hujjah dan sumber hukum islam. $^{12}$

2. Sunah

Sebagaimana hadis dari Aisyah dan Abdullah bin Umar berikut:

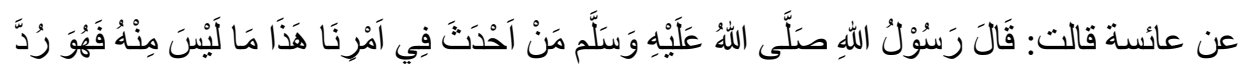

Rasul SAW bersabda: barang siapa yang membuat hal baru, yang tidak termasuk bagian dari ajaranku maka ditolak.

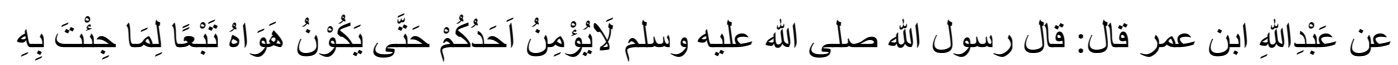

Rasul SAW bersabda: Tidak beriman salah seorang di antara kamu sampai hawa nafsunya tunduk pada apa yang aku bawa.

Dan beberapa hadis lain yang menegaskan bahwa sunah merupakan sumber hukum islam setelah al-Qur'an. ${ }^{13}$

3. Ijma'

Para sahabat sepakat untuk mengikuti sunah Rasul SAW dan kembali ke Sunah bila tidak menemukan hukum suatu masalah di dalam Al-Qur'an.

4. Dalil Aqli

Setiap orang yang berakal mengetahui bahwa orang yang dipercaya sebagai Nabi pasti bisa dipercaya segala apa yang keluar darinya dan wajib diikuti. Disamping itu al-Qur'an sebagai sumber primer hukum Islam tidak menjelaskan secara rinci mengenai tata cara maupun syarat dari beberapa perintah yang dibebankan kepada umat sehingga melalui Rasul SAW semuanya akan menjadi lebih jelas. Jika sunah

\footnotetext{
${ }^{11}$ Q.S. al-Nisa (4): 80.

${ }^{12}$ Ibrahim, Asbab al-ikhtilafi al-fuqaha fi al-ahkam al-syar'iyyah.........., 263. Lihat pula Achmad el Ghandur. Perspektif Islam. Terj Ma'mun Muhammad Murai. (Yogyakarta: Pustaka Fahima, 2006), 125-126.

${ }^{13}$ Ibrahim, Asbāb al-ikhtilāfi al-fuqahā fi al-ahkam al-syar'iyyah............., 263-264.
} 
tidak berfungsi sebagai hujjah, maka manusia akan kesulitan dalam melakukan perintah yang dibebankan. ${ }^{14}$

Dari beberapa dalil di atas, umat Islam sepakat mengenai kewajiban mengikuti Rasul SAW dan beranggapan bahwa setiap orang dapat dipegang ucapanya dan ditinggalkan kecuali Rasulullah SAW. Jika seorang ahli fiqh menghukumi sesuatu bertentangan dengan yang ditetapkan Rasul SAW maka hal itu karena sunah Rasul tidak sampai kepadanya atau sampai tapi sunah itu tidak sah menurutnya.

Mengenai Urgensi sunah dapat kita ketahui dari segi dilalahnya atau hukum-hukum yang terkandung di dalamnya, yaitu:

a) Sunah berfungsi menetapkan dan memperkuat hukum-hukum yang telah ditentukan oleh al-Qur'an. Sehingga hukum itu memiliki dua sumber yaitu al-Qur'an sebagai sumber utama dan sunah sebagai ta'qid (penguat). Sebagaimana diharamkannya bersaksi palsu di dalam al-Qur'an berikut ini:

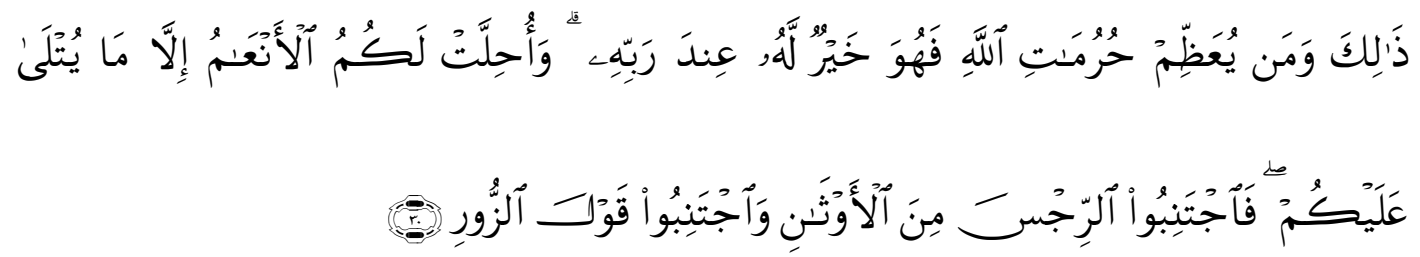

"Demikianlah (perintah Allah) dan barangsiapa mengagungkan apa-apa yang terhormat di sisi Allah maka itu adalah lebih baik baginya di sisi Tuhannya dan telah dihalalkan bagi kamu semua binatang ternak, terkecuali yang diterangkan kepadamu keharamannya, Maka jauhilah olehmu berhala-berhala yang najis itu dan jauhilah perkataan-perkataan dusta". ${ }^{15}$

Ayat tersebut kemudian dikuatkan oleh Hadis Nabi yang berbunyi:

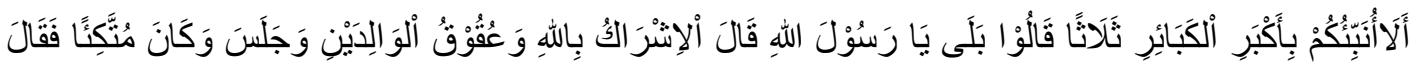

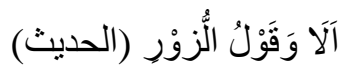

"Perhatikan, aku akan memberitahukan kepadamu sekalian tentang dosa yang paling besar, sahut kami: "baiklah, hai Rasulullah, beliau meneruskan sabdanya: 1) menyekutukan Allah; 2) durhaka kepada kedua orang tua. Saat itu Rasul SAW

\footnotetext{
${ }^{14}$ Sulaiman Abdullah, Sumber Hukum Islam: Permasalahan dan Fleksibilitasnya (Jakarta: Sinar Grafika, 1995), 26-27.

${ }^{15}$ QS. al-Hajj (22): 30.
} 
Ririn Fauziah

sedang bersandar, tiba-tiba duduk seraya bersabda lagi: “awas berkata palsu” (HR. Bukhari Muslim). ${ }^{16}$

b) Memberikan perincian dan penafsiran ayat-ayat al-Qur'an yang masih mujmal atau global (bayan al-mujmal), memberikan batasan terhadap hal-hal yang belum terbatas (taqyid al-mutlaq), memberikan kekhususan (takhsis) ayat-ayat yang bersifat umum (takhshish al-amm), dan memberikan penjelasan terhadap hal-hal yang masih rumit di dalam al-Qur'an. ${ }^{17}$

Contoh bayan al-mujmal:

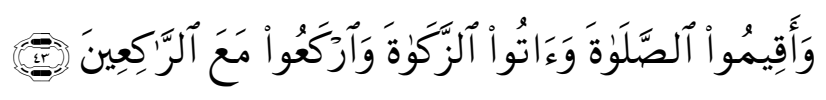

“Dan Dirikanlah shalat, tunaikanlah zakat dan ruku'lah beserta orang-orang yang $r u k u^{\prime \prime \prime} \cdot 18$

Salat di dalam al-Qur'an hanya disebutkan secara global mengenai wajibnya shalat tanpa dijelaskan kaifiyah (cara-cara) menjalankannya, jumlah rakaatnya, dan sebagainya secara terperinci. Hal ini dijelaskan dalam Hadis berikut ini:

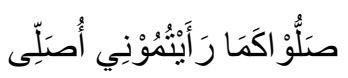

“Ṣalatlah kamu sekalian sebagaimana kamu melihat aku mengerjakan s\}alat” (HR. Bukhari Muslim).

Hadits ini menunjukkan bahwa Rasul SAW memberikan contoh praktis tentang caracara menjalankan ibadah shalat.

Contoh taqyid al-muthlaq:

Di dalam al-Qur'an disebutkan tentang ketentuan anak dapat mewarisi harta orang tua dan keluarganya sebagai berikut:

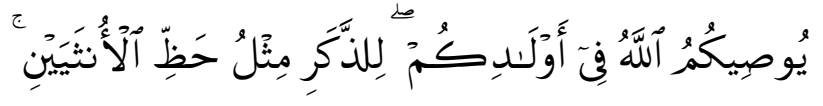

"Allah mensyari'atkan bagimu tentang (pembagian pusaka untuk) anak-anakmu. yaitu:bahagian seorang anak lelaki sama dengan bagahian dua orang anak perempuan ". 19

\footnotetext{
${ }^{16}$ Muhaimin, et al. Kawasan dan Wawasan Studi Islam (Jakarta: Kencana, 2005), 134-135.

${ }^{17}$ Ismail Muhammad Syah, Filsafat Hukum Islam (Jakarta: Bumi Aksara, 1992), 41.

${ }^{18}$ QS. al-Baqarah (2): 43.

${ }^{19}$ QS. al-Nisa' (4): 11.
} 
Di dalam ayat tersebut tidak dijelaskan batasan (syarat-syarat) untuk saling mewarisi antara mereka. Kemudian hadis mengemukakan batasan (syarat), tidak berlainan agama dan tidak adanya tindakan pembunuhan. Sebagaimana sabda Nabi SAW:

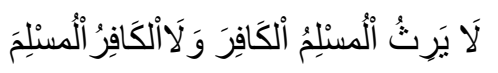

"Si muslim tidak boleh mewarisi harta kafir dan si kafir pun tidak boleh mewarisi harta si muslim." (HR. Jamaah)

Contoh takhsish al-amm:

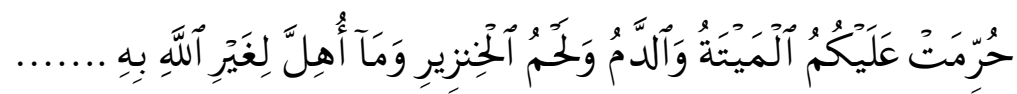

"Diharamkan bagimu (memakan) bangkai, darah, daging babi, (daging hewan) yang disembelih atas nama selain Allah......." 20 .

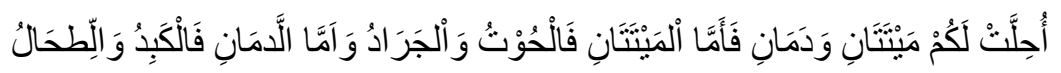

"Dihalalkan bagi kita dua macam bangkai dan dua macam darah. Adapun dua macam bangkai itu adalah bangkai ikan dan bangkai belalang, sedang dua macam darah itu ialah hati dan limpa”. (HR. Ibnu Majah dan Ahmad) ${ }^{21}$

Al-Qur'an mengharamkan bangkai dan darah secara umum, namun Hadis di atas mengecualikan dua bangkai dan dua macam darah yang halal.

c) Sunah sebagai pembentuk hukum baru yang belum ada dalam al-Qur'an, sehingga sumber yang digunakan adalah Sunah. Seperti masalah sanksi terhadap pezina yang sudah bersuami. Dalam al-Qur'an ia dihukum dengan 100 kali cambukan, kemudian sunah menambahkannya dengan hukum rajam.

Para ulama telah sepakat mengenai fungsi sunah sebagai penguat dan penjelas terhadap al-Qur'an, namun mengenai fungsi sunah sebagai pembentuk hukum baru yang belum ada dalam al-Qur'an masih menjadi perselisihan di antara ulama. Sebagian ulama berpendapat bahwa sunah tidak mandiri dalam menetapkan hukum, tetapi bersandar pada nash umum al-Qur'an sehingga sunah bertugas menjelaskan dan mencabangkannya. Sedangkan sebagian yang lain beranggapan bahwa sunah memang membentuk hukum secara mandiri. Sebagaimana diharamkannya mengumpulkan antara seorang wanita dengan bibinya,

\footnotetext{
${ }^{20}$ QS. al-Maidah (5): 3.

${ }^{21}$ Muhaimin, et al. Kawasan dan Wawasan Studi Islam. $136-137$
} 
haramnya hewan yang berkuku tajam dan hewan buas yang bertaring, dan beberapa hukum lain yang tidak terdapat di dalam al-Qur'an. Sunah dengan kemandiriannya menetapkan keharamannya. $^{22}$

Dalam hal ini Imam Syafi'i mencoba memberikan alasan terhadap pendapat yang menerima fungsi sunah sebagai pembentuk hukum yang tidak terdapat dalam al-Qur'an, yaitu:

1) Rasul SAW memiliki otoritas untuk menetapkan sesuatu yang tidak terdapat di dalam al-Qur'an dengan catatan selama Rasul diyakini ma'sum, maka tidak ada halangan untuk menetapkan syari'at sendiri. Sehingga Rasul berhak untuk menetapkan hukum yang tidak di atur dalam al-Qur'an.

2) Banyak ayat al-Qur'an yang menunjukkan wajib taat kepada Rasul SAW, termasuk apa yang ditetapkan.

3) Banyak Hadis yang menunjukkan bahwa sunah dan al-Qur'an merupakan rujukan utama.

Sedang pendapat yang kedua menganggap bahwa apapun yang ditetapkan oleh sunah sebenarnya telah ditetapkan di dalam al-Qur'an. Al-Qur'an hanya berfungsi sebagai penjelas dan semua yang diucapkan, dilakukan, dan ditetapkan Rasul adalah kembali kepada alQur'an. ${ }^{23}$ Sesungguhnya tidak ada perbedaan antara kedua pendapat di atas karena pada hakikatnya mereka sepakat adanya ketetapan baru dari sunah, hanya saja pendapat yang pertama menyatakan bahwa ketetapan itu berdiri sendiri sedang pendapat yang kedua menyatakan bahwa ketetapan tersebut tidak terlepas dari al-Qur'an.

\section{Penutup}

Sunah menurut bahasa adalah: cara yang biasa dilakukan, baik berupa cara yang baik atau buruk. Sedangkan menurut istilah Sunah adalah: segala suatu yang bersumber dari Rasulullah SAW berupa perkataan, perbuatan, dan ketetapan.

Macam-macam Sunah dari segi dzatnya dibagi menjadi 3 macam, yaitu: sunah qauliyah, sunah fi'liyah, dan sunah taqrïriyah. Sunah qauliyah adalah: segala yang diucapkan Rasul SAW baik dalam bentuk pernyataan, anjuran, perintah, cegahan, maupun larangan. Sedang Sunah fi'liyah ('amaliyah) adalah segala perbuatan Rasul SAW yang disaksikan oleh

\footnotetext{
${ }^{22}$ Salim Ali al-Bahanasawi, Rekayasa as-Sunah. Terj. Abdul Basith Junaidy. (Yogyakarta: Ittaqa Press, 2001), 21-22.

${ }^{23}$ Fathurrahman Djamil. Filsafat Hukum Islam (Jakarta: Logos Wacana Ilmu, 1997), 98-100.
} 
sahabat meliputi masalah ibadah, muamalah, dan sebagainya. Sunah Taqririyah adalah: sikap diam Rasulullah SAW saat mengetahui peristiwa yang dilakukan para sahabat baik berupa ucapan, atau perbuatan, baik kejadian itu terjadi di hadapan Rasul SAW atau berita tersebut sampai kepada Rasul SAW.

Sunah berfungsi menjelaskan dan memperkuat hukum-hukum yang telah ada di dalam al-Qur'an. Sunah juga memberikan perincian dan penafsiran ayat-ayat al-Qur'an yang masih mujmal atau global, memberikan batasan terhadap hal-hal yang belum terbatas, memberikan kekhususan (takhsis) pada ayat-ayat yang bersifat umum, dan memberikan penjelasan terhadap hal-hal yang masih rumit di dalam al-Qur'an. Sunah juga berfungsi sebagai pembentuk hukum baru yang belum ada dalam al-Qur'an.

\section{Daftar Pustaka}

Abdullah, Sulaiman. Sumber Hukum Islam: Permasalahan dan Fleksibilitasnya. Jakarta: Sinar Grafika, 1995.

Abu Zahrah, Muhammad. Ușülal-Fiqh Kairo: Dar al-Fikr al-Arabi, t. th.

Ali al-Bahanasawi, Salim. Rekayasa as-Sunah. Terj. Abdul Basith Junaidy. Yogyakarta: Ittaqa Press, 2001.

Djamil, Fathurrahman. Filsafat Hukum Islam Jakarta: Logos Wacana Ilmu, 1997.

Ghandur, (el) Achmad. Perspektif Islam. Terj Ma'mun Muhammad Murai. Yogyakarta: Pustaka Fahima, 2006.

Ibrahim, Musthafa. Asbābu ikhtilafi al-fuqahā fi al-ahkām al-syar'iyyah. Bagdad: Darul Arabiyyah, 1987.

Muhaimin, et al. Kawasan dan Wawasan Studi Islam Jakarta: Kencana, 2005.

Muhammad Syah, Ismail. Filsafat Hukum Islam. Jakarta: Bumi Aksara, 1992.

Rahman, Zufran. Kajian Sunah Nabi SAW Sebagai Sumber Hukum Islam: Jawaban Terhadap Aliran Inkar Sunah Jakarta: CV Pedoman Ilmu Jaya, 1995.

Syarifuddin, Amir. Ușūl al-Fiqh, Jakarta: Logos Wacana Ilmu, 1997.

Tim Penyusun Studi Islam IAIN Ampel. Pengantar Studi Islam. Surabaya: Sunan Ampel Press, 2010. 